\title{
Factors Leading to Endometritis in Dairy Cows in Egypt with Special Reference to Reproductive Performance
}

\author{
Mohamed GHANEM ${ }^{1) \#}$, Abedel Hamid SHALABY1), Sayed SHARAWY1) and \\ Nashet SALEH ${ }^{1)}$ \\ 1) Theriogenology Department, Faculty of Veterinary Medicine, Suez Canal University, \\ Ismailia, Egypt \\ \#Present: Laboratory of Animal Science, IDEC, Hiroshima University, Higashi-Hiroshima 739- \\ 8529, Japan
}

\begin{abstract}
The incidence of endometritis and risk factors between herds and between breeds and its effect on the subsequent fertility of cows may differ among countries. It is therefore necessary to study the etiology of endometritis in these different circumstances. This work was carried out on 190 Holstein Friesian cows (2.5-13 years old) belonging to El-Salhia Agriculture project (Ismailia Province, Egypt) during the period from January 1996 to April 1997. The incidence of endometritis was $22.4 \%$, and the most prominent risk factors leading to the occurrence of endometritis were retained placenta, stillbirth, external interference by herdmen during calving and difficult birth (20.6, $19.1,12.3$ and $5.3 \%$ respectively). The cows in the first parity had a higher incidence of endometritis $(27.7 \%)$ than cows in the subsequent parities. Cows which calved in autumn (31.2\%) had a higher incidence of endometritis than cows which calved in the other seasons. The endometritic cows had inferior reproductive indices than the normal cows. The interval between calving and first service in cows with endometritis was 14 days longer than the normal ones. The first service conception rate $(12.5 \%)$ and final conception rate $(45.5 \%)$ in cows with endometritis were lower than those in the normal cows (50 and 100\%) $(\mathrm{P}<0.05)$. In conclusion the most important risk factors leading to endometritis are retained placenta and abnormal calving in dairy cows in Egypt. Moreover, postpartum endometritis adversely affects subsequent fertility in dairy cows in Egypt.
\end{abstract}

Key words: Cattle, Endometritis, Risk factors, Reproductive performance

(J. Reprod. Dev. 48: 371-375, 2002)

R

eproductive inefficiency in lactating dairy cows is a major problem in many dairy herds. A significant proportion of the problems related to reproduction can be attributed to varying degrees of endometritis.

The losses due to infertility and improper breeding in Egyptian cattle and buffaloes have been reported to be more than 100 million Egyptian pounds (77 millions \$) annually [1].

Abnormal parturition and puerperal

Accepted for publication: March 13, 2002

Correspondence: M. Ghanem complication play an important role in bovine infertility. The retention of fetal membranes is considered one of the most serious postpartum disorders [2]. Besides, abortion, stillbirth, dystocia, and laceration or lesion in the uterus, cervix, vagina and vulva can also result in persistent endometritis [3].

Endometritis in cows has determinal effects on subsequent reproductive performance. The interval from calving to first estrus and first service is delayed in cows with endometritis [4]. The first service conception rate is usually decreased in 
cows with endometritis compared with normal cows, and the calving to conception interval is also increased in cows with endometritis compared with cows without endometritis [5]. And cows with endometritis require more services per conception than cows without endometritis [4].

The aim of the present work is to investigate the incidence of endometritis in dairy cows and its effect on subsequent reproductive performance and some predisposing factors which lead to the occurrance of endomeritis in dairy cows in Egypt.

\section{Materials and Methods}

\section{Animals}

One hundered and ninty Holstein Friesian cows belonging to El-Salhia Agriculture project (ElSalhia city, Ismailia Province, Egypt) were used during the period from January 1996 to April 1997 in this study. The total number of cows on the farm was 760 Holstein Friesian. One hundered and seventy cows were diagnosed clinically with chronic endometritis and twenty cows without endometritis were used as normal control animals. Age ranged from 2.5 to 13 years, and parity ranged from 1 to 10 .

All cows were kept under the same nutritional and managemental conditions during the period of the study. The cows were milked three times daily (3:00 a.m., 1:00 p.m. and 9:00 p.m.) in a parlour. The average lactation period was 300 days. Lactating cows were divided into several groups based upon days in lactation and milk yield. The cows were dried 2 months before the expected date of delivery.

\section{Breeding history of the cows}

Information concerning the breeding history of each cow was collected from the farm breeding records and included the number of previous calvings, date and condition of the last parturition, occurrence of any calving problems, explusion of fetal membranes, occurrence of any puerperal disorders, date of the first estrus after parturition, date of the first service after parturition, number of previous services and date of the last service, regularity and frequency of estrus cycles and visual character of any vaginal discharge.

\section{Clinical examination of the cows}

One hundred and ninty cows were clinically examined rectally and by vaginoscopy, 35 days post partum. Twenty regular cycling cows were selected on the basis of the absence of cervicitis and endometritis according to the principle recommended by Roberts [3] and served as a control group. In these control cows no clinical disease was observed during the experiment. Cases of endometritis (170 cows) were classified into mucoid endometritis (E1), mucopurulent endometritis (E2), and purulent endometritis (E3). Endometritis in the postpartum period is generally associated with delayed involution of the uterus, abnormal vaginal discharge and slow recovery of the endometrium. Subsequently, during estrus the affected cows may have abnormal vaginal discharge containing clumps of pus in the mucus. On rectal examination the uterus may feel slightly enlarged and thick walled. The cows came regularly or irregularly to estrus

\section{Evaluation of data}

The following parameters were calculated: the incidence of endometritis, the incidence of calving problems and puerperal disorders that may lead to endometritis and the incidence of endometritis in relation to parity and the season of calving. Reproductive parameters concerning calving to conception interval, days from calving to the first estrus, interval from calving to natural mating, number of services per conception, conception rate at the first service (\%) and total number of cows which conceived among twenty-four cows with endometritis were compared to the normal cows. Pregnancy was confirmed by palpation per rectum at 50-60 days after mating.

\section{Statistical analysis}

All the data obtained in the present study were statistically analyzed according to SAS [6].

\section{Results}

\section{Incidence of chronic endometritis}

The incidence of chronic endometritis was $22.4 \%$ in all the cows on the farm. Among the predisposing factors leading to the occurrence of endometritis were retained placenta $(20.6 \%)$, stillbirth (19.4\%) and external interference during 
Table 1. Distribution of different predisposing factors in relation to the different degrees of endometritis

\begin{tabular}{lcccccccc}
\hline & \multicolumn{7}{c}{ Degree of endometritis } \\
Predisposing factors & \multicolumn{2}{c}{ E1 } & \multicolumn{2}{c}{ E2 } & \multicolumn{2}{c}{ E3 } & \multicolumn{2}{c}{ Total } \\
\cline { 2 - 9 } & No. & $\%$ & No. & $\%$ & No. & $\%$ & No. & $\%$ \\
\hline Retained placenta & 3 & 12.5 & 9 & 10.8 & 23 & 36.5 & 35 & 20.6 \\
Stillbirth & 5 & 20.8 & 13 & 15.7 & 15 & 23.8 & 33 & 19.4 \\
External interference & 5 & 20.8 & 9 & 10.8 & 7 & 11.1 & 21 & 12.4 \\
Difficult birth & 0 & 0 & 4 & 4.8 & 5 & 7.9 & 9 & 5.3 \\
Puerperal metritis & 0 & 0 & 0 & 0 & 5 & 7.9 & 5 & 2.9 \\
Laceration of genitalia & 3 & 12.5 & 0 & 0 & 2 & 3.2 & 5 & 2.9 \\
Abortion & 0 & 0 & 1 & 1.2 & 2 & 3.2 & 3 & 1.8 \\
Hypocalcemia & 0 & 0 & 1 & 1.2 & 1 & 1.6 & 2 & 11.2 \\
Cows without & 8 & 33.3 & 46 & 55.4 & 3 & 4.8 & 57 & 33.5 \\
predisposing factors & & & & & & & & \\
\hline Total & 24 & 100 & 83 & 100 & 63 & 100 & 170 & 100 \\
\hline
\end{tabular}

E1: mucoid endometritis, E2: mucopurulent endometritis, E3: purulent endometritis

calving $(12.4 \%)$, whereas the lowest risk factors were abortion $(1.8 \%)$ and hypocalcemia $(1.2 \%)$ (Table 1). Cows in the first parity had the highest incidence of endometritis $(27.7 \%)$, whereas those that had delivered more than 6 times had the lowest incidence $(4.1 \%)$ (Table 2$)$. With regard to the relationship between the calving season and the incidence of endometritis, it was evident that calving in autumn was accompanied with a higher incidence of endometritis (31.2\%). In spring and winter the incidence was similar (25.3 and $24.7 \%$ ). The lowest incidence of endometritis was observed when calving had occurred in summer $(18.8 \%)$ (Table 3).

\section{Effect of chronic endometritis on subsequent reproductive performance in cows}

The difference between cows with endometritis and normal cows in reproductive indices is shown in Table 4. There was a significant difference $(\mathrm{P}<$ $0.05)$ between cows with endometritis and the normal cows especially in the number of services required for conception $(3.4 \pm 0.1$ vs. $1.4 \pm 0.1)$. The mean calving to the first estrus interval was delayed about 14 days more in the endometritic cows than in the normal ones. The mean calving to conception interval was significantly longer $(\mathrm{P}<$ 0.05 ) in endometritic cows than in the normal ones $(151.5 \pm 8.2$ vs. $92.9 \pm 6.2)$. The percentage of first service conceptions and percentage of cows which conceived were lower in cows with endometritis than in the normal cows (12.5 and 45.8 vs. 50 and $100 \%$ ), respectively.
Table 2. The number of cows with chronic endometritis in relation to the their parity

\begin{tabular}{ccc}
\hline Parity & No. of cows with endometritis & $\%$ \\
\hline 1 & 47 & 27.7 \\
2 & 34 & 20.0 \\
3 & 31 & 18.2 \\
4 & 35 & 20.6 \\
5 & 16 & 9.4 \\
$6-10$ & 7 & 4.1 \\
\hline Total & 170 & 100 \\
\hline
\end{tabular}

Table 3. The relationship between the season of last calving and the number of cows with chronic endometritis

\begin{tabular}{lcc}
\hline $\begin{array}{l}\text { Calving } \\
\text { season }\end{array}$ & $\begin{array}{c}\text { No. of cows with } \\
\text { endometritis }\end{array}$ & $\%$ \\
\hline Autumn & 53 & 31.18 \\
Spring & 43 & 25.29 \\
Winter & 42 & 24.71 \\
Summer & 32 & 18.82 \\
\hline Total & 170 & 100 \\
\hline
\end{tabular}

\section{Discussion}

The incidence of endometritis on the farm was $22.4 \%$. This result was similar to that obtained by Slimane et al. [7]. Concerning the predisposing factors leading to the occurrence of chronic endometritis, it was shown that the retention of placenta was the most important factor leading to endometritis as $20.6 \%$ of the total number of cows suffering from chronic endometritis had a history 
Table 4. Comparison of different reproductive indices in cows with endometritis and normal control cows

\begin{tabular}{lcccccc}
\hline Item & $\begin{array}{c}\text { No. of } \\
\text { cows }\end{array}$ & $\begin{array}{c}\text { No. of services } \\
\text { per conception }\end{array}$ & $\begin{array}{c}\text { Calving to } \\
\text { the first } \\
\text { estrus }\end{array}$ & $\begin{array}{c}\text { Calving to } \\
\text { conception } \\
\text { interval }\end{array}$ & $\begin{array}{c}\text { first service } \\
\text { concep rate } \\
(\%)\end{array}$ & $\begin{array}{c}\text { total concep } \\
\text { rate }(\%)\end{array}$ \\
\hline Cows with endom. & 24 & $3.4 \pm 0.1^{* a}$ & $91.1 \pm 5.4$ & $151.5 \pm 8.2^{* \mathrm{c}}$ & 12.5 & 45.8 \\
Normal control cows & 20 & $1.4 \pm 0.1^{\mathrm{b}}$ & $77.5 \pm 6.5$ & $92.9 \pm 6.3^{\mathrm{d}}$ & 50 & 100 \\
\hline
\end{tabular}

* Means \pm SE. a/b .c/d Significant difference at $(\mathrm{P}<0.05)$.

of placental retention after calving. The results obtained were consistent with those of Peter and Ball [8]. The higher incidence of endometritis $(22.3 \%)$ observed in the study might be due to the higher incidence of retained fetal membrane after calving. Placental retention resulted in low fertility [9], delayed onset of first behavioural estrus and resumption of the estrous cycle after calving [10], and a decrease in the rate of uterine involution in the postpartum period [8].

Dohoo and Martin [11], concluded that retained fetal membranes might have little direct effect on reproductive performance but increase infections of the reproductive tract. There was a close positive relationship between retained fetal membranes and metritis, and the uterus is considered at high risk of infection for at least a month [12]. Noticeable dilation of the cervix, vagina and vulva at calving allows the entrance of many species of bacteria from the outside. But the cervix remains relaxed for several days after parturition, allowing some of these bacteria to gain access to the uterus. In some cows, uterine damage may not be as extensive as in those that develop pyometra but Corynebacterium Pyogenes becomes established in the endometrium leading to chronic metritis and infertility. Retained placenta could alter the uterine environment, resulting in endometritis. Stillbirth was considered an important factor for increasing the frequency of endometritis [3]. Of the 170 cows with endometritis $47(27.7 \%)$ were in the first parity. This might be due to the fact that the primiparous cows needed external interference and personnel assistance more that the multiparous cows. This finding was consistent with those of Markusfeld [13] who stated that endometritis occurred mostly in their first lactation. It was observed that cows which calved in autumn, spring and winter had a relatively higher incidence of endometritis than those which delivered in summer (31.2, 25.3 and 24.7 vs. $18.8 \%$ respectively). These findings were in agreement with those of Arthur [14, 15], but not with the results reported by Dubois and Williams [16], who stated that the incidence of puerperal endometritis was higher in summer (May to September) than in the rest of the year. The higher incidence of endometritis in autumn, spring and winter might be due to an unhygienic calving environment during the seasons in which rainfall may dampen the ground. Variations in the results may be due to differences in hygienic measurements taken during mating, calving, puerperium and the type of housing [3]. Moreover, non specific causes such as endocrine dysfunction, malnutrition and excessive milk production have a certain effect not less than that of bacteria in causing endometritis.

In cows with endometritis, the interval from calving to the first estrus was delayed about 14 days as compared to the normal cows. This finding was simillar to the results reported by Sandals et al. [17]. The first service conception rate was reduced by $38 \%$, whereas the calving to conception interval was significantly $(\mathrm{P}<0.05)$ prolonged by 55 days in postpartum cows affected with endometritis as compared to the normal ones. These findings agreed with those of Lourens [4] and Nakao et al. [5]. Furthermore, the number of services per conception was higher ( 3.37 vs. 1.35 ) in cows with endometritis than that in the normal cows. These findings were similar to those reported by Lourens [4]. It could be concluded that cows with postpartum chronic endometritis had a significantly inferior reproductive performance than normal cows.

Moreover, endometritis leads to irritation of the uterine mucosa. This inflammation had either a toxic effect on sperm due to bacterial toxins or varied the hydrogen ion concentration in the uterus in a manner harmful to the sperm or the fertilized ovum, leading to a large proportion of unsuccessful conceptions. 


\section{Acknowledgement}

The authors thank Prof. T. Nakao, Prof. of
Domestic Animal Reproduction, IDEC, Hiroshima Univ. for his revision and correction of this paper.

\section{References}

1. Osman AM. Ovarian inactivity and repeat breeder syndrome in buffaloes with possible treatment. J Egypt Vet Med Ass 1984; 44: 85-98.

2. Holt LC, Whittier WD, Gwazdaukas FC, Vinson WE. Early postpartum reproductive profiles in Holstein cows with retained placenta and uterine discharges. J Dairy Sci 1989; 72: 533-539.

3. Roberts SJ. Injuries and diseases of the puerperal period. In: Roberts SJ, (ed.), Veterinary Obestetric and Genital Diseases. 3rd ed. Woodstock; VT: published by the author, 1986: 353-396.

4. Lourens DC. A comparative observational study on the reproductive performance of dairy cows with metritis and normal cows. South African J Anim Sci 1995; 25: 21-25.

5. Nakao T, Moriyoshi M, Kawata K. The effect of postpartum ovarian dysfunction and endometritis on subsequent reproductive performance in high and medium producing dairy cows. Theriogenology 1992; 37: 341-349.

6. SAS Users Guide. Statistics Version 6 ed. SAS Institue Inc. NC: Cary. 1990.

7. Slimane N, Ahmadi C, Ouali F, Kachti M, Thibier M. Epidemiological and clinical analysis of post puerperal endometritis in dairy cows. Recueil de Medecine Veterinaire 1994; 170: 823-832.

8. Peters AR, Ball PJ. Reproduction in Cattle. 2nd ed. Oxford: Blackwell science Ltd., 1995.

9. Grunert E, Grunert D. The problems of the success of after birth removal in cattle. Expert veterinary opinion. Tieraztl Prax 1990; 18: 473-476.

10. Schindler H, Eger S, Davidson M, Ochowski D, Schermerhorn EC, Foote RH. Factors affecting response of groups of dairy cows managed for different calving-conception intervals. Theriogenology 1991; 36: 495-503.

11. Dohoo IR, Martin SW. Disease, production, and culling in Holstein Friesian cows. IV. Effects of disease on production. Prev Vet Med 1984; 2: 755.

12. Squire AG. Current Therapy in Theriogenology. 2nd ed., Morrow AD (ed.,) Philadelphia: WB Saunders Co., 1986.

13. Markusfeld O. Factors responsible for postparturient metritis in dairy cattle. Vet Rec 1984; 114: 539-542.

14. Arthur GH, Noakes DE, Pearson H. Veterinary Reproduction and Obstetrics. 7th ed. London: Bailliere, Tindall; 1996.

15. Dhami AJ, Patel DM, Panchal MT, Derashri HJ, Dave MR. Studies on breeding patterns and reproductive losses in dairy cattle and buffaloes of Gujarat state. Ind Vet Med J 1993; 17: 97-102.

16. Dubois PR, Williams, DJ. Increased incidence of retained placenta associated with heat stress in dairy cow. Theriogenology 1980; 13: 115-121.

17. Sandals WC, Curtiss RA, Cote JF, Martin SW. The effect of retained placenta metritis complex on reproductive performance in dairy cattle. A case control study. Can Vet J 1979; 20: 131-139. 